\title{
Quercetin inhibits transforming growth factor $\beta I$-induced epithelial-mesenchymal transition in human retinal pigment epithelial cells via the Smad pathway
}

\author{
Wenting Cai ${ }^{1, *}$ \\ Donghui Yu ${ }^{1}, *$ \\ Jiaqi Fan ${ }^{2}$ \\ Xiuwei Liang ${ }^{3}$ \\ Huizi Jin' \\ Chang Liu ${ }^{2}$ \\ Meijiang Zhu' \\ Tianyi Shen' \\ Ruiling Zhang' \\ Weinan $\mathrm{Hu}^{4}$ \\ Qingquan $\mathrm{Wei}^{1}$ \\ Jing $Y u^{1,5}$
}

'Department of Ophthalmology, Shanghai Tenth People's Hospital Affiliated with Tongji University,

Shanghai, People's Republic of China;

${ }^{2}$ Department of Ophthalmology,

Nanjing Medical University,

Nanjing, People's Republic of China;

${ }^{3}$ Department of Ophthalmology,

Nanchang University, Nanchang,

People's Republic of China;

${ }^{4}$ Department of Ophthalmology, Anhui

University of Science and Technology,

Huainan, People's Republic of China;

${ }^{5}$ Department of Ophthalmology,

Ninghai First Hospital, Zhejiang,

People's Republic of China

*These authors contributed equally to this work

Correspondence: Jing Yu

Department of Ophthalmology, Shanghai

Tenth People's Hospital Affiliated with

Tongji University, 30I Middle Yanchang

Road, Shanghai 200072, People's Republic of China

Tel +86 21 I89I 7683348

Email dryujing@aliyun.com
This article was published in the following Dove Press journal:

Drug Design, Development and Therapy

\begin{abstract}
Purpose: The purpose of this study was to evaluate the effect and mechanism of quercetin on TGF- $\beta 1$-induced retinal pigment epithelial (RPE) cell proliferation, migration, and extracellular matrix secretion.
\end{abstract}

Materials and methods: Cell counting kit- 8 , transwell, wound-healing assays, and ELISA were used to assess viability, migration, and collagen I secretion, respectively. Western blot analysis and qPCR were employed to detect mRNA and protein expression levels, respectively.

Results: Quercetin suppressed TGF- $\beta 1$-induced cell proliferation, migration, and collagen I secretion. The results also showed that mRNA and protein expression of epithelial-mesenchymal transition (EMT)-related markers such as alpha-smooth muscle actin and N-cadherin was downregulated by quercetin in TGF- $\beta 1$-treated RPE cells; conversely, quercetin upregulated the expression of E-cadherin and tight junction protein 1 (ZO-1). In addition, quercetin could inhibit mRNA and protein expression of matrix metalloproteinases. Quercetin may reverse the progression of EMT via the Smad2/3 pathway.

Conclusion: Our results demonstrate the protective effects of quercetin on RPE cell EMT, revealing a potential therapeutic agent for proliferative vitreoretinopathy treatment.

Keywords: proliferative vitreoretinopathy, quercetin, epithelial-mesenchymal transition, transforming growth factor- $\beta 1$

\section{Introduction}

Proliferative vitreoretinopathy (PVR) is a vision-threatening disease commonly associated with rhegmatogenous retinal detachment (RD). RD is the separation of the neurosensory retina from the linked retinal pigment epithelium. The intravitreal growth factors and cytokines after occurrence of RD may influence postoperative outcomes. Statistically, PVR occurs in 5\%-10\% of RD patients, especially postoperatively. ${ }^{1}$ Progression of PVR involves several steps, such as the proliferation and migration of retinal pigment epithelial (RPE) and glial cells, the formation and contraction of the proliferative membrane, the production of extracellular collagen, and the formation of retinal folds. ${ }^{2}$ The epithelial-mesenchymal transition (EMT) plays a vital role in the progression of PVR. Following the stimulation by several factors, polarized epithelial cells switch to a mesenchymal cell phenotype, producing an extracellular matrix (ECM) and exhibiting changes in morphological and molecular characteristics. ${ }^{3}$

Some studies have indicated that multiple growth factors and cytokines are involved in the vitreous body of PVR patients, including tumor necrosis factor- $\alpha$, BY ${ }_{\mathrm{NC}}$ and incorporate the Creative Commons Attribution - Non Commercial (unported, v3.0) License (http://creativecommons.org/licenses/by-nc/3.0/). By accessing the work you
hereby accept the Terms. Non-commercial uses of the work are permitted without any further permission from Dove Medical Press Limited, provided the work is properly attributed. For permission for commercial use of this work, please see paragraphs 4.2 and 5 of our Terms (https://www.dovepress.com/terms.php). 
interleukin-(IL-) 6, transforming growth factor-beta (TGF- $\beta$ ) and epidermal growth factor (EGF). ${ }^{4}$ In our previous studies, TGF- $\beta 1$ was found to have an essential role in EMT in RPE cell lines (ARPE-19). ${ }^{5,6}$ TGF- $\beta 1$-induced EMT triggers epithelial cells to alter their epithelial phenotype to one with mesenchymal characteristics, and the proliferation, migration, and collagen generation of TGF- $\beta 1$-induced RPE cells are enhanced, accelerating EMT progression. Some therapeutic methods have recently been proposed for reversing EMT development both in vitro and in vivo, such as the application of flavonoids or gene silencing. For example, Ren et al reported that curcumin inhibits RPE cell proliferation via downregulation of EGF and thus effectively inhibits the development of PVR. ${ }^{7}$ In 2013, protein kinase $\mathrm{C} \alpha$ silencing was demonstrated to have effect on suppressing RPE cell proliferation and migration, which was crucial against PVR disease. ${ }^{8}$ The degradations of collagen and other ECM proteins were closely associated with matrix metalloproteinases (MMPs). The MMP-2 and MMP-9 were expressed in higher levels in PVR patients, which played a vital role in the subretinal membrane formation and cell migration. ${ }^{9,10}$ However, despite the large number of studies of EMT in PVR treatment, no therapeutic drugs have been developed in the last few decades to effectively prevent PVR.

Quercetin is a natural polyphenolic flavonoid compound extracted from plants such as Phyllanthus emblica. ${ }^{11}$ Some studies have reported that quercetin has many beneficial properties such as antioxidant, ${ }^{12,13}$ anti-inflammation, ${ }^{14}$ antimicrobial, ${ }^{15}$ anti-angiogenesis, ${ }^{16,17}$ and anticancer properties. ${ }^{18,19}$ Wang et al found that quercetin was able to upregulate certain oxidative stress-related genes such as $\mathrm{Cu} / \mathrm{Zn}$ superoxide dismutase (SOD-1) and catalase (CAT) in vivo and in vitro. ${ }^{13}$ Quercetin also downregulates vascular endothelial growth factor receptor (VEGFR) expression, blocking angiogenesis in retinoblastoma. ${ }^{17}$ According to another report, quercetin conjugated with nanoparticles exhibited an anti-angiogenic effect on breast cancer via the epidermal growthfactorreceptor/VEGFR-2(EGFR/VEGFR-2)mediated pathway. ${ }^{16}$ In addition, quercetin appears to have effects in several ocular diseases such as age-related macular degeneration, ${ }^{20}$ diabetic cataract (DC), ${ }^{21}$ dry eye, ${ }^{22}$ and retinoblastoma. ${ }^{17} \mathrm{Xu}$ et al demonstrated that quercetin could protect oxidative damage via activation of the Nrf2 pathway. ${ }^{23}$ In 2017, Du et al reported that quercetin had a potential therapeutic effect on DC, alleviating EMT by inhibiting the TGF- $\beta / \mathrm{PI} 3 \mathrm{~K} / \mathrm{Akt}$ pathway. ${ }^{21}$ In 2013 , Stoddard et al indicated that quercetin could protect the corneal epithelium from oxidative damage by decreasing reactive oxygen species production. $^{24}$

Nonetheless, it remains unclear whether quercetin could inhibit TGF- $\beta 1$-induced EMT progression and associated signaling in RPE cells.

\section{Materials and methods Cell culture and treatment}

Human retinal pigment epithelium (ARPE-19) cells were purchased from iCell Bioscience Inc. (Shanghai, China) and cultured in DMEM/F-12 (Thermo Fisher Scientific, Waltham, MA, USA) supplemented with 10\% FBS, $100 \mathrm{U} / \mathrm{mL}$ penicillin and streptomycin. The cells were grown at $37^{\circ} \mathrm{C}$ in $5 \% \mathrm{CO}_{2}$-air. The cells with good shape and in good growth status were used in our experiments. The culture medium was changed every $2-3$ days. Upon reaching $60 \%-70 \%$ confluence, the cells were treated with FBS-free DMEM/F-12 culture medium for 24 hours to simulate starvation conditions before experiments. The ARPE-19 cells were incubated with $0,2.5,5,7.5,10,12.5$, and $15 \mathrm{ng} / \mathrm{mL}$ TGF- $\beta 1$ (PeproTech Inc., Rocky Hill, NJ, USA) and 0, 25, 50, 60, 75 , and $100 \mu \mathrm{mol} / \mathrm{L}$ quercetin (Sigma-Aldrich Co., St Louis, MO, USA) for 24 and 48 hours. The following four groups were established: Group A, control; Group B, $10 \mathrm{ng} / \mathrm{mL}$ TGF- $\beta 1$; Group C, 10 ng/mL TGF- $\beta 1+25 \mu \mathrm{mol} / \mathrm{L}$ quercetin; and Group D, $10 \mathrm{ng} / \mathrm{mL}$ TGF- $\beta 1+50 \mu \mathrm{mol} / \mathrm{L}$ quercetin.

\section{Cell viability assay}

Cell viability was measured using cell counting kit-8 (CCK-8 assay; Yeasen, Shanghai, China). ARPE-19 cells were seeded in 96-well plates at a density of 2,000 cells/well in $100 \mu \mathrm{L}$ cultural medium and then starved in FBS-free DMEM/F-12 culture medium for 12 hours before stimulation with TGF- $\beta 1$ at various concentrations of TGF- $\beta 1$ and treatment with quercetin. After incubation as described above for 24 and 48 hours, $10 \mu \mathrm{L}$ of CCK- 8 reagent was added to each well for another 2 hours. Cell viability was analyzed spectrophotometrically at $450 \mathrm{~nm}$, with the numbers of living, metabolically active cells being reflected in the absorbance values.

\section{Wound healing assay}

The above four groups of cells were plated in six-well plates at $1 \times 10^{5}$ cells per well. At $80 \%$ confluence, wounds were created with a $200 \mu \mathrm{L}$ pipette tip in the middle of the monolayer, and the wells were washed with PBS. Images were acquired at 0 hours as a starting point, and the cells were treated as described above. Wound closure was recorded after incubation for 24 and 48 hours by measuring the 
scratch widths, and migration rates were calculated based on the formula (distance/scratch width) $\times 100 \%$. Duplicated wells for each group were used, and the experiments were repeated three times.

\section{Transwell assay}

The four groups of cells were treated as mentioned above. A total of $5 \times 10^{4}$ cells in $200 \mu \mathrm{L}$ of FBS-free DMEM/F-12 culture medium were seeded in the upper compartment of a transwell system ( $8 \mathrm{~mm}$ pore size; Corning Incorporated, Corning, NY, USA); culture medium with $10 \%$ FBS was added to the lower compartment. After incubation for 18 hours, non-migratory cells were removed with cotton swabs. After washing with PBS, the migrated cells attached to the bottom membrane were fixed with ethanol for 20 minutes and stained with $1 \%$ crystal violet for 15 minutes after drying in air. Images in three fields were acquired under phasecontrast microscopy $(100 \times)$.

\section{Type I collagen ELISA}

The human Col I ELISA kit (Shanghai Saige Biotechnology Co Ltd, Shanghai, China) was used according to the manufacturer's protocol to assess cell supernatant type I collagen (Col I) secretion. Cells were seeded in six-well plates at a density of $2 \times 10^{5}$ cells per well and exposed to four different treatments. All groups were cultured for 48 hours. The supernatants were collected, and Col I concentrations were measured at $492 \mathrm{~nm}$; values were calculated using a standard curve.

\section{RNA extraction and qRT-PCR}

Total cellular RNA was extracted using TRIzol reagent (Thermo Fisher Scientific) according to the manufacturer's protocol, and a NanoDrop 2000 spectrophotometer was employed to quantify RNA concentrations. PrimerScript RT reagent Kit (TaKaRa Bio Inc., Osaka, Japan) was used to synthesize cDNA. The relative expression level of each gene was detected according to 7500 Fast Real-time PCR System (Thermo Fisher Scientific), as normalized with GAPDH in three replications. The primer sequences are presented in Table 1.

\section{Western blotting}

RIPA lysis buffer was used to lyse cells to extract total protein. The supernatant was collected after centrifugation $(12,000 \mathrm{rpm}$, $4^{\circ} \mathrm{C}, 10$ minutes), and the total protein concentration was quantified using a BCA Protein Assay kit (Beyotime, Shanghai, China). Cytosolic and nuclear protein were isolated using a Nuclear and Cytoplasmic Protein Extraction Kit, respectively, according to
Table I Nucleotide sequences of primers used for PCR

\begin{tabular}{|c|c|c|}
\hline Gene & & Primer sequence $\left(5^{\prime}-3^{\prime}\right)$ \\
\hline \multirow[t]{2}{*}{ ZO-I } & Forward & CAACATACAGTGACGCTTCACA \\
\hline & Reverse & САCTATTGACGTTTCCCСАСTC \\
\hline \multirow[t]{2}{*}{$\alpha$-SMA } & Forward & AAAAGACAGCTACGTGGGTGA \\
\hline & Reverse & GCCATGTTCTATCGGGTACTTC \\
\hline \multirow[t]{2}{*}{ E-cadherin } & Forward & CGAGAGCTACACGTTCACGG \\
\hline & Reverse & GGGTGTCGAGGGAAAAATAGG \\
\hline \multirow[t]{2}{*}{$\mathrm{N}$-cadherin } & Forward & TCAGGCGTCTGTAGAGGCTT \\
\hline & Reverse & ATGCACATCCTTCGATAAGACTG \\
\hline \multirow[t]{2}{*}{ MMP-2 } & Forward & TACAGGATCATTGGCTACACACC \\
\hline & Reverse & GGTCACATCGCTCCAGACT \\
\hline \multirow[t]{2}{*}{ MMP-9 } & Forward & TGTACCGCTATGGTTACACTCG \\
\hline & Reverse & GGCAGGGACAGTTGCTTCT \\
\hline \multirow[t]{2}{*}{ GAPDH } & Forward & GGAGCGAGATCCCTCCAAAAT \\
\hline & Reverse & GGCTGTTGTCATACTTCTCATGG \\
\hline
\end{tabular}

the manufacturer's instructions (Beyotime) and also quantified using a BCA Protein Assay kit. Proteins were separated by $8 \%-10 \%$ SDS-PAGE and transferred onto nitrocellulose membranes. The membranes were blocked in non-fat milk dissolved in Tween-20/PBS buffer for 1 hour at room temperature and incubated overnight with primary antibodies including antiZO-1, -alpha-smooth muscle actin (- $\alpha$-sma), -E-cadherin, -Ncadherin, -Smad2/3, -MMP-9, and -GAPDH antibodies (1:1,000,\#8193,\#19245,\#3195,\#13116,\#3102,\#8828,\#2270, \#5174, respectively, Cell Signaling Technology, Danvers, MA, USA) and anti-MMP-2 (1:1,000, ARG55236; Arigo Biolaboratories, Shanghai, China). The membranes were washed three times for 10 minutes each in Tween-20/PBS buffer, followed by incubation of secondary goat anti-rabbit antibodies for 45 minutes at room temperature in the dark. An Odyssey two-color infrared laser imaging system (LI-COR Biosciences, Lincoln, NE, USA) was used to scan the membranes.

\section{Immunofluorescence staining}

ARPE-19 cells were seeded and cultured in $35 \mathrm{~mm}$ confocal dishes (glass-bottom dishes) and then fixed with $4 \%$ paraformaldehyde for 10 minutes. The cells were permeabilized and blocked for 1 hour at room temperature with $0.1 \%$ Triton $\mathrm{X}-100$ and 5\% BSA dissolved in PBS and then incubated overnight at $4{ }^{\circ} \mathrm{C}$ with primary antibodies (all 1:100 dilution). The cells were incubated with Fluorescein isothiocyanate (FITC)-conjugated secondary antibodies for 40 minutes after washing three times with PBS. Next, nuclei were stained with DAPI (1:1,000 dilution) for 20 minutes. Images were obtained by confocal microscopy (LSM710; Carl Zeiss, Jena, Germany). 


\section{Statistical analyses}

Statistical analyses were performed with GraphPad Prism version 5 (GraphPad Software, Inc., La Jolla, CA, USA) and SPSS 19.0 (IBM Corporation, Armonk, NY, USA) software packages. Data are expressed as mean \pm standard deviation (SD), based on results from three separate experiments. One-way ANOVA was performed for multiple groups. $P$-values $<0.05$ were considered statistically significant.

\section{Results}

\section{Effects of quercetin on TGF- $\beta$ I-induced cell proliferation in ARPE- 19 cells}

ARPE-19 cells were treated with different concentrations of TGF- $\beta 1(0,2.5,5,7.5,10,12.5$, and $15 \mathrm{ng} / \mathrm{mL})$. As shown in Figure 1A, cell proliferation was stimulated, except at $12.5 \mathrm{ng} / \mathrm{mL}$, by TGF- $\beta 1$ at 24 and 48 hours in a concentrationdependent manner, especially after 48 hours (Figure 1A).
Next, the cells were treated with various concentrations of quercetin to observe effects on cell viability. No cytotoxicity in ARPE-19 cells was found for quercetin for concentrations $<100 \mu \mathrm{mol} / \mathrm{L}$ at 24 hours and $60 \mu \mathrm{mol} / \mathrm{L}$ at 48 hours, as shown in Figure 1B. Moreover, quercetin inhibited TGF$\beta 1$-induced cell proliferation at 25 and $50 \mu \mathrm{mol} / \mathrm{L}$ after 24 and 48 hours, respectively (Figure 1C).

\section{Effects of quercetin on TGF- $\beta$ I-induced ARPE- 19 cell migration}

Quercetin-suppressed wound closure in TGF- $\beta$ I-induced ARPE- 19 cells

For the wound-healing test, the width of the opening was measured at 0, 24, and 48 hours, as shown in Figure 2, and the ratios of ( $24 \mathrm{~h}-0 \mathrm{~h}) / 0$ hour and $(48 \mathrm{~h}-0 \mathrm{~h}) / 0$ hour were calculated. Migration by TGF- $\beta 1$-treated cells was greater than that of cells not treated with TGF- $\beta 1$ at both 24 and
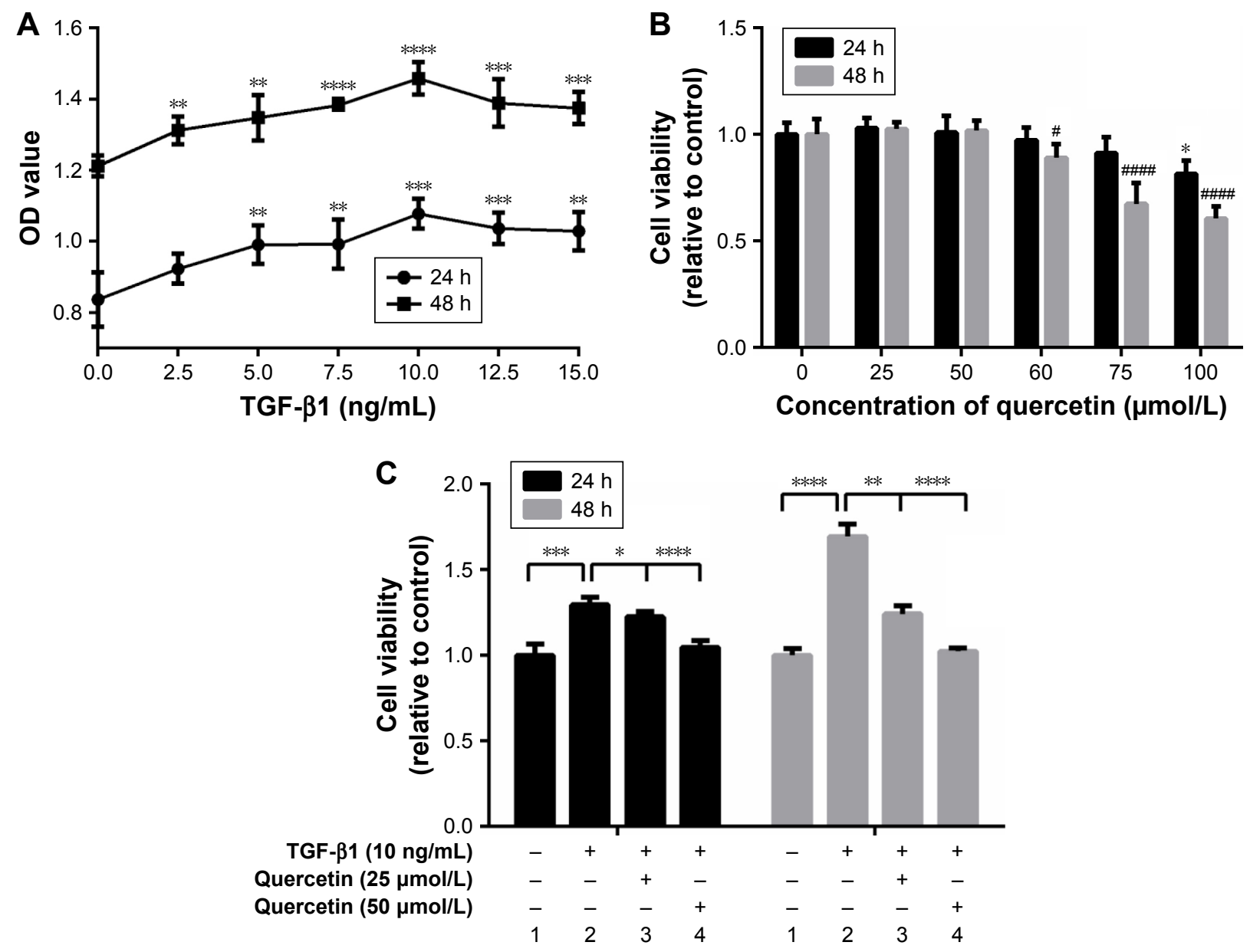

Figure I Effects of quercetin on the cell viability of ARPE-19 cells stimulated by TGF- $\beta$ I.

Notes: (A) The cells were treated with different concentrations of TGF- $\beta$ I $(0,2.5,5,7.5,10,12.5$, and I $5 \mathrm{ng} / \mathrm{mL}$, respectively) for 24 and 48 hours, and the cell viability was determined by CCK-8 assay. ${ }^{*} * P<0.01$, *** $P<0.00$ I, $* * * * P<0.000$ I vs the OD value of cells cultured without TGF- $\beta$ I. (B) Different concentrations of quercetin $(0,25,50$, 60,75 , and $100 \mu \mathrm{mol} / \mathrm{L}$, respectively) were incubated in ARPE-19 cells for 24 and 48 hours. The cell viability was detected. $* P<0.05$ vs the control group without quercetin treatment for 24 hours, ${ }^{\# P}<0.05, \ldots P<0.000$ I vs the cells treated without quercetin for 48 hours. (C) The cells were treated with or without quercetin (50 and $100 \mu$ mol/L) in TGF- $\beta$ I-stimulated ARPE- 19 cells for 48 hours, and cell viability was measured using a CCK- 8 assay. The data are shown as mean \pm SEM; $n=3$.

Abbreviations: CCK-8, cell counting kit-8; TGF- $\beta$, transforming growth factor- $\beta$. 
A
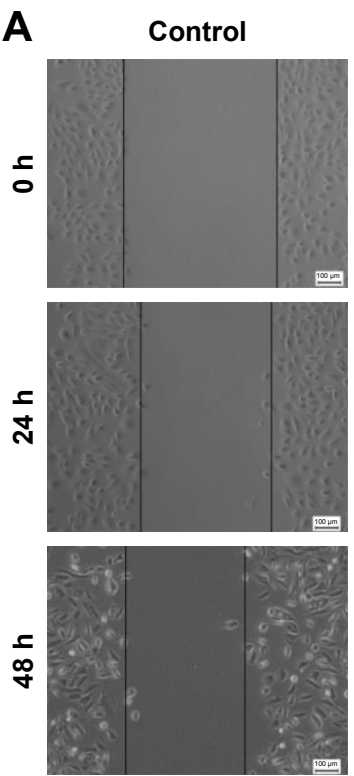

B

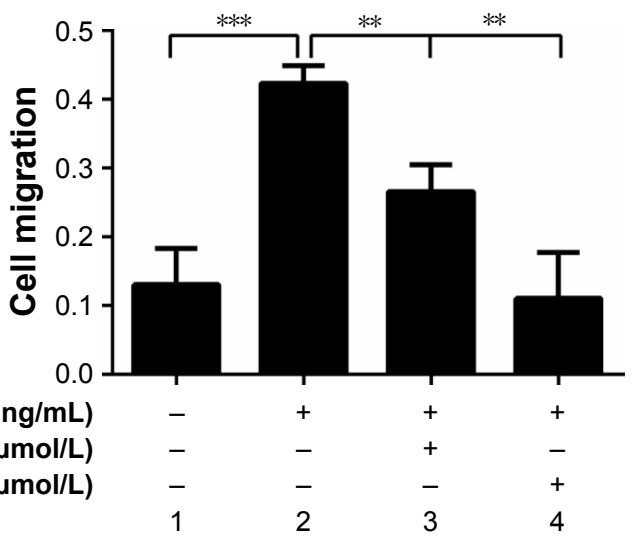

$\mathrm{T}+25 \mu \mathrm{mol} / \mathrm{L}$ que
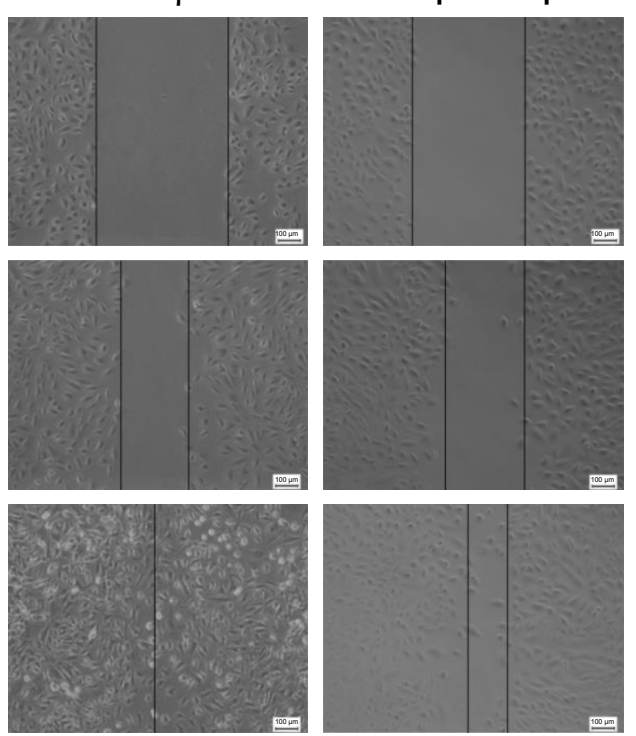

$\mathrm{T}+50 \mu \mathrm{mol} / \mathrm{L}$ que
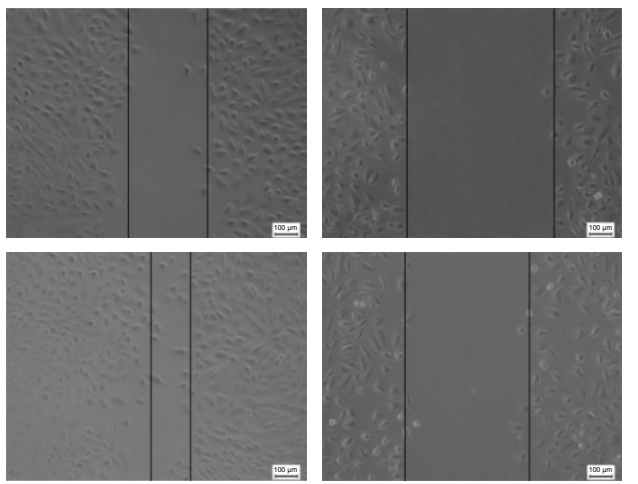

C

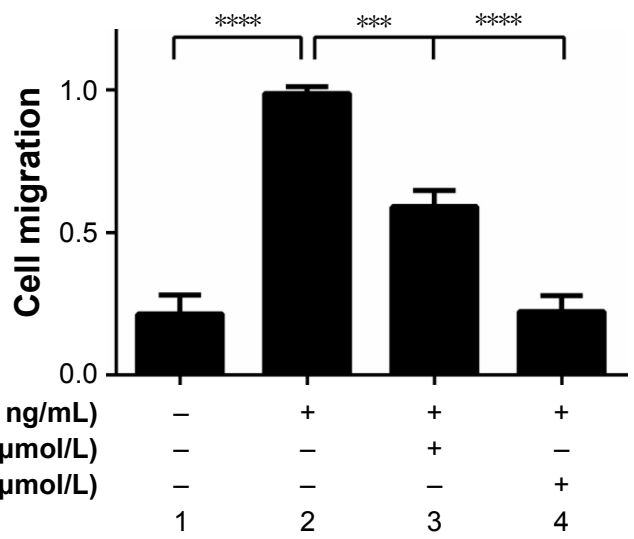

Figure 2 Effects of quercetin on wound closure in TGF- $\beta$ I-treated RPE cells.

Notes: (A) RPE cells were pretreated with or without $10 \mathrm{ng} / \mathrm{mL}$ of TGF- $\beta$ I in the absence of 25 or $50 \mu \mathrm{M}$ quercetin after a scratch. The images were captured at 0,24 , and 48 hours in four groups. The migratory length was calculated according to the scratch at 0 hour. The data are representative of at least three independent experiments. Magnification: $\times 100$. (B) Cell migration data at 24 hours were quantified in wound closure via recording migration length. (C) Cell migration data at 48 hours were quantified in wound closure via recording migration length. The data are shown as mean $\pm \mathrm{SEM} ; \mathrm{n}=3$. $* * P<0.01, * * * P<0.001, * * * * P<0.000 \mathrm{I}$.

Abbreviations: que, quercetin; RPE, retinal pigment epithelial; TGF- $\beta$, transforming growth factor- $\beta$.

48 hours $(* * * P<0.001$ and $* * * * P<0.0001$, respectively). Quercetin attenuated TGF- $\beta 1$-induced cell migration in a concentration-dependent manner. The migration rates at 24 hours decreased from $0.42 \pm 0.03$ in TGF- $\beta 1$-treated cells to $0.27 \pm 0.04$ and $0.11 \pm 0.07$ at 25 and $50 \mu \mathrm{mol} / \mathrm{L}$ in quercetin-treated cells, respectively. The migration rates of the four groups were $0.21 \pm 0.067,0.99 \pm 0.02,0.59 \pm 0.06$, and $0.22 \pm 0.05$ at 48 hours.

Quercetin-suppressed TGF- $\beta$ I-induced cell migration The transwell assay was employed to evaluate cell migration. The numbers of cell migrating after stimulation with TGF- $\beta 1$ were increased from $164.00 \pm 28.48$ to $457.00 \pm 22.11$ at 24 hours $(* * * P<0.001)$, and quercetin reduced these numbers to $316.67 \pm 30.55(* * P<0.01)$ and $161.33 \pm 32.96$
$(* * * P<0.001)$ at concentrations of 25 and $50 \mu \mathrm{mol} / \mathrm{L}$, respectively. The numbers for the four groups after incubation for 48 hours were $259.67 \pm 29.09,422.00 \pm 38.00$, 186.00 \pm 55.57 , and 152.33 \pm 20.65 . These results showed that quercetin significantly inhibited TGF- $\beta 1$-induced cell migration in a concentration-dependent and time-dependent manner (Figure 3).

\section{Effects of quercetin on TGF- $\beta$ I-treated cell collagen I secretion in ARPE-I 9 cells}

As shown in Figure 4, $10 \mathrm{ng} / \mathrm{mL}$ of TGF- $\beta 1$ promoted cell collagen I secretion at 48 hours. The concentration of collagen $\mathrm{I}$ in the culture supernatant increased from $44.16 \pm 0.54$ to $51.20 \pm 0.48 \mathrm{ng} / \mathrm{mL}$ but was significantly reduced after treatment with quercetin. 
A
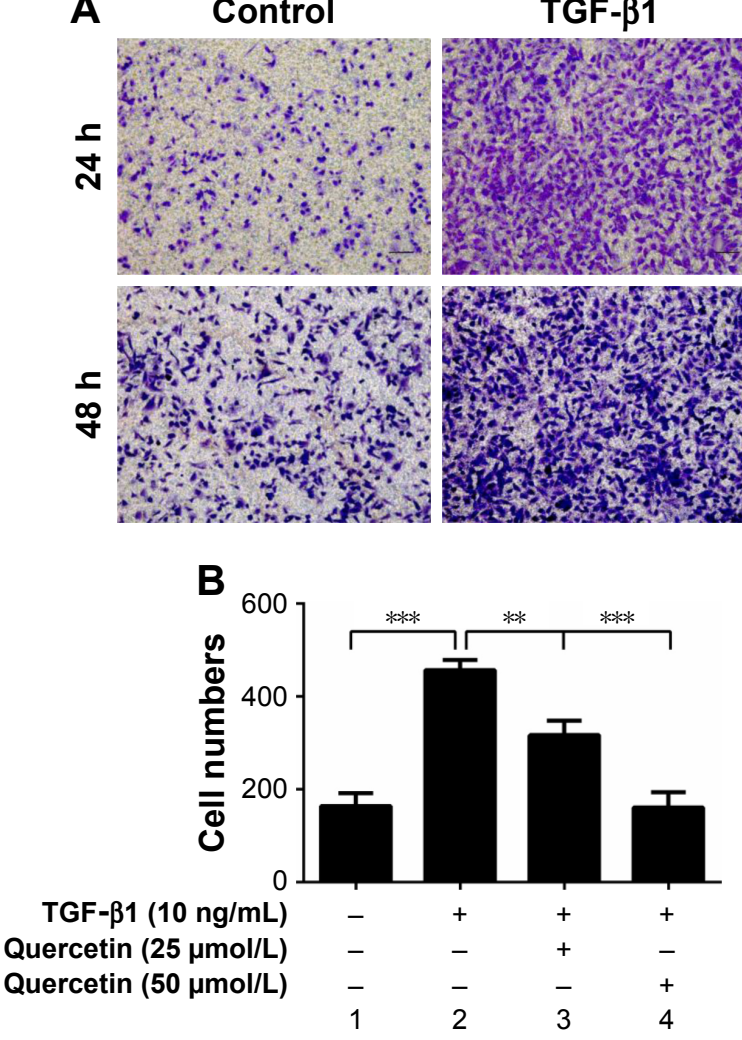

TGF- $\beta 1$
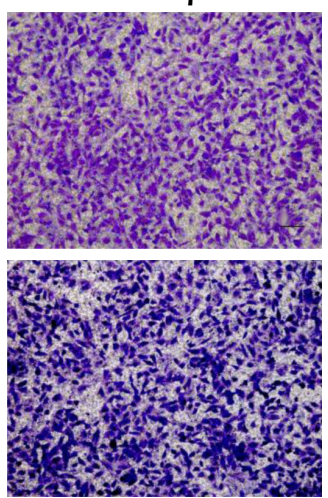

B
$\mathrm{T}+25 \mu \mathrm{mol} / \mathrm{L}$ que $\quad \mathrm{T}+50 \mu \mathrm{mol} / \mathrm{L}$ que

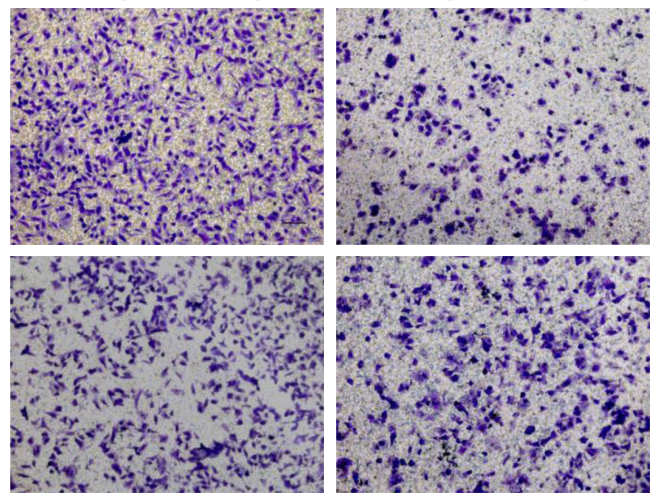

TGF- $\beta 1(10 \mathrm{ng} / \mathrm{mL})$

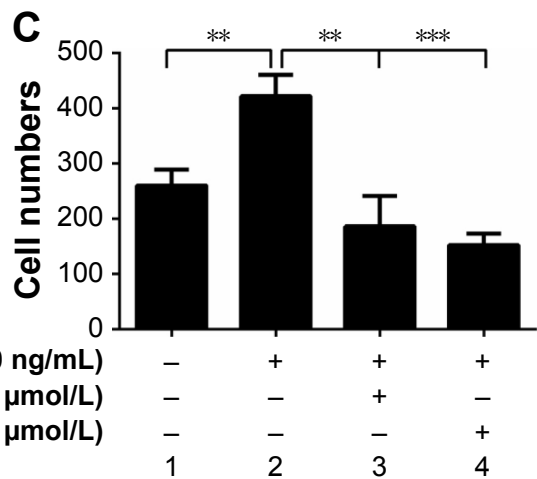

Figure 3 Effects of quercetin on cell migration in TGF- $\beta$ I-treated RPE cells.

Notes: (A) After treatment with $10 \mathrm{ng} / \mathrm{mL}$ of TGF- $\beta$ I with or without quercetin ( 50 and $100 \mu \mathrm{M})$ for 48 hours, the migration of RPE cells with different treatments were detected via transwell migration analysis. Migrated cells at $24 \mathrm{~h}(\mathbf{B})$ and $48 \mathrm{~h}(\mathbf{C})$ were quantified by counting three random vision fields under a microscope. Magnification $\times 100$. The data are shown as mean \pm SEM. $n=3$. $* * P<0.01$, $* * * P<0.001$. Scale bar: $100 \mu \mathrm{m}$.

Abbreviations: que, quercetin; RPE, retinal pigment epithelial; TGF- $\beta$ I, transforming growth factor- $\beta$ I.

\section{Effects of quercetin on TGF- $\beta$ I-induced MMP-2 and MMP-9 expressions in ARPE- 19 cells}

As shown in Figure 5, $10 \mathrm{ng} / \mathrm{mL}$ of TGF- $\beta 1$ promoted the mRNA and protein expression of MMP-2 and MMP-9 at

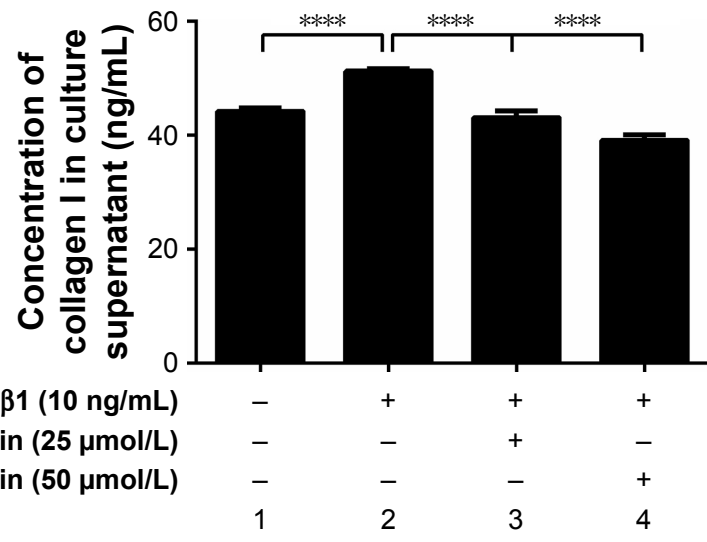

Figure 4 Effect of quercetin on collagen I secretion in TGF- $\beta$ I-treated RPE cells. Notes: The supernatants were collected after incubation with or without quercetin and TGF- $\beta$ I for 48 hours. The concentration of collagen I was quantified via ELISA. $* * * * P<0.000$ I.

Abbreviations: RPE, retinal pigment epithelial; TGF- $\beta$ I, transforming growth factor- $\beta$ I.
48 hours. Meanwhile, quercetin significantly decreased the levels of expression of MMP-2 and MMP-9 in a concentrationdependent manner.

\section{Effects of quercetin on expression of EMT} markers in TGF- $\beta$ I-induced RPE cells

Quercetin reversed mRNA and protein expression of ZO-I, E-cadherin, N-cadherin, and $\alpha$-SMA during TGF- $\beta$ I-induced EMT in ARPE- 19 cells

As shown in Figure 6, qPCR and Western blot analyses demonstrated an increase in the expression levels of the mesenchymal markers $\mathrm{N}$-cadherin and $\alpha$-SMA after TGF- $\beta 1$ incubation; however, quercetin significantly decreased the levels of expression of mesenchymal markers in a concentration-dependent manner. Moreover, expression of the epithelial marker ZO-1 and E-cadherin was significantly decreased after treatment with TGF- $\beta 1$, whereas that of ZO-1 and E-cadherin was increased by exposure to quercetin. Based on immunofluorescence staining, quercetin significantly upregulated the expression of ZO-1 and E-cadherin while downregulating N-cadherin and $\alpha$-SMA (Figure 7). 


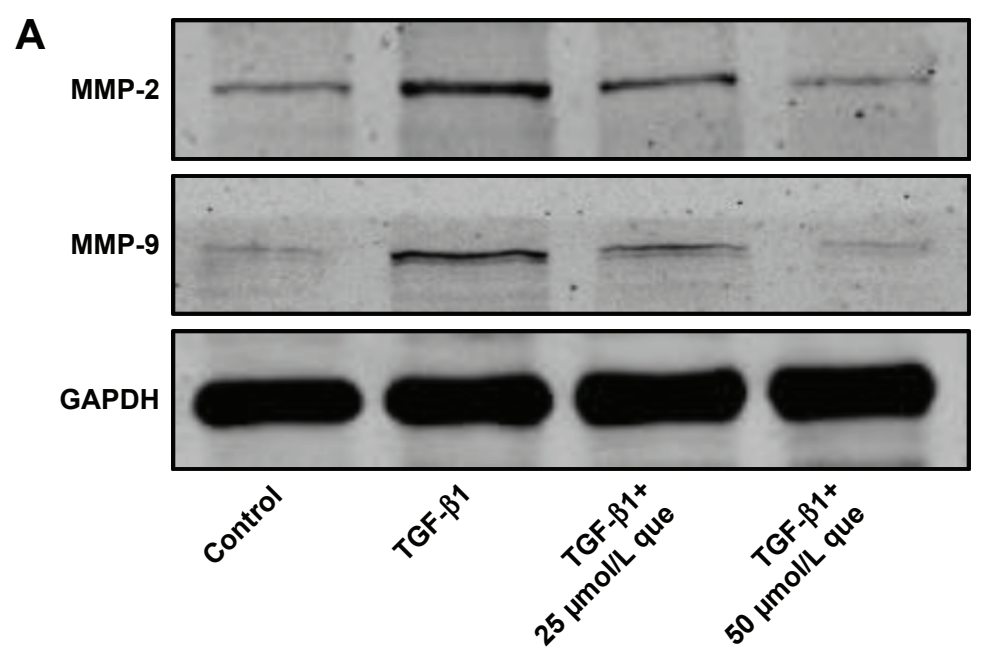

B

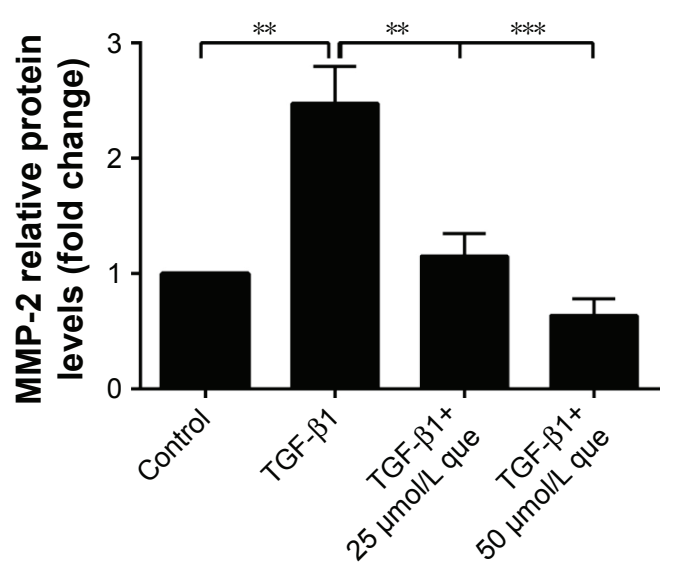

D

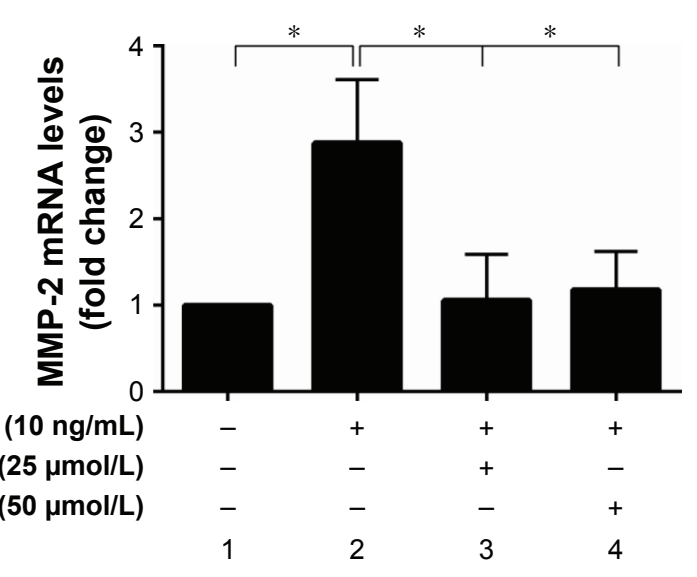

C

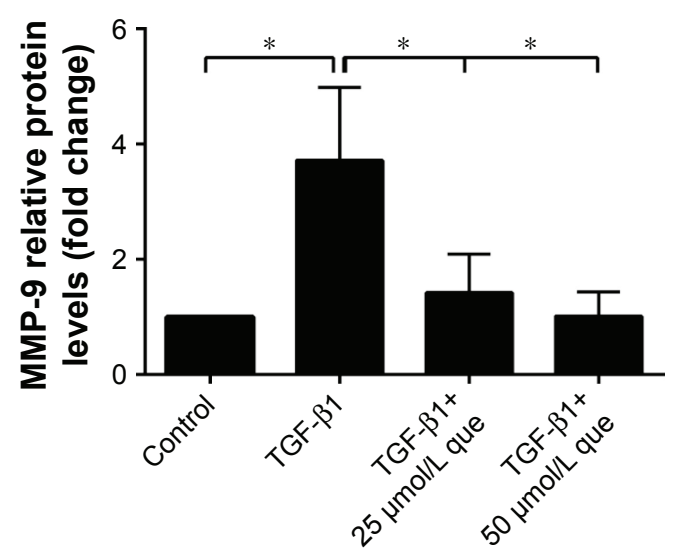

E

TGF- $\beta 1(10 \mathrm{ng} / \mathrm{mL})$ Quercetin $(25 \mu \mathrm{mol} / \mathrm{L})$ Quercetin $(50 \mu \mathrm{mol} / \mathrm{L})$

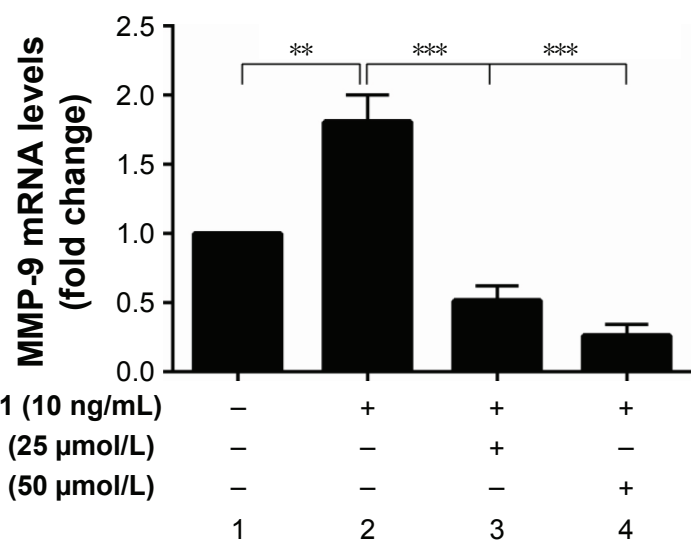

Figure 5 Quercetin suppressed TGF- $\beta$ I-induced MMP expression in RPE cells.

Notes: (A) The protein levels of MMP-2 and MMP-9 were detected by Western blot in TGF- $\beta$ I and quercetin-treated RPE cells for 48 hours. (B and C) Relative protein expression (normalized to GAPDH) was quantified in Western blots via recording gray scale values. (D and E) The mRNA levels of MMP-2 and MMP-9 were detected by real-time PCR. The data are presented as mean \pm SEM. $n=3$. *P<0.05, **P $<0.01$, ****P<0.001.

Abbreviations: MMP-2, matrix metalloproteinase-2; MMP-9, matrix metalloproteinase-9; que, quercetin; RPE, retinal pigment epithelial; TGF- $\beta$ I, transforming growth factor- $\beta$ I.

Quercetin-suppressed expression of phosphorylatedSmad2/3 and nuclear translocation of Smad4 during TGF- $\beta$ I-induced EMT in ARPE-19 cells

We then investigated the effect of quercetin on the Smad signaling pathway, which has been identified as an important factor for EMT. Phosphorylation of $\mathrm{Smad} 2 / 3$ was significantly increased after TGF- $\beta 1$ treatment, contributing to EMT progression. In addition, cytosolic protein of Smad4 was decreased while nuclear protein of Smad4 was increased after TGF- $\beta 1$ incubation, which indicated that Smad4 was transported into the nucleus. Interestingly, incubation with quercetin inhibited $\operatorname{Smad} 2 / 3$ phosphorylation 
and translocation of Smad4. In summary, these results suggest that quercetin inhibits TGF- $\beta 1$-induced EMT in ARPE-19 cells by suppressing phosphorylation of $\operatorname{Smad} 2 / 3$ (Figure 8).

\section{Discussion}

The results of our study show that quercetin inhibits TGF$\beta 1$-induced EMT in RPE cells by regulating phosphorylation of Smad2/3 pathway components. Based on our data, we propose that quercetin might serve as a therapeutic agent in the treatment of PVR.

PVR, which involves a wound-healing process, is the most common cause of anatomic failure in RD surgery and a challenge in the clinic. Several cells such as RPE cells, Müller glia cells, macrophages, and fibroblasts are known to participate during the development of PVR. ${ }^{25}$ RPE cells have been reported to de-differentiate, proliferate, and migrate through retinal holes onto the retinal surface..$^{26,27}$ Müller glia release
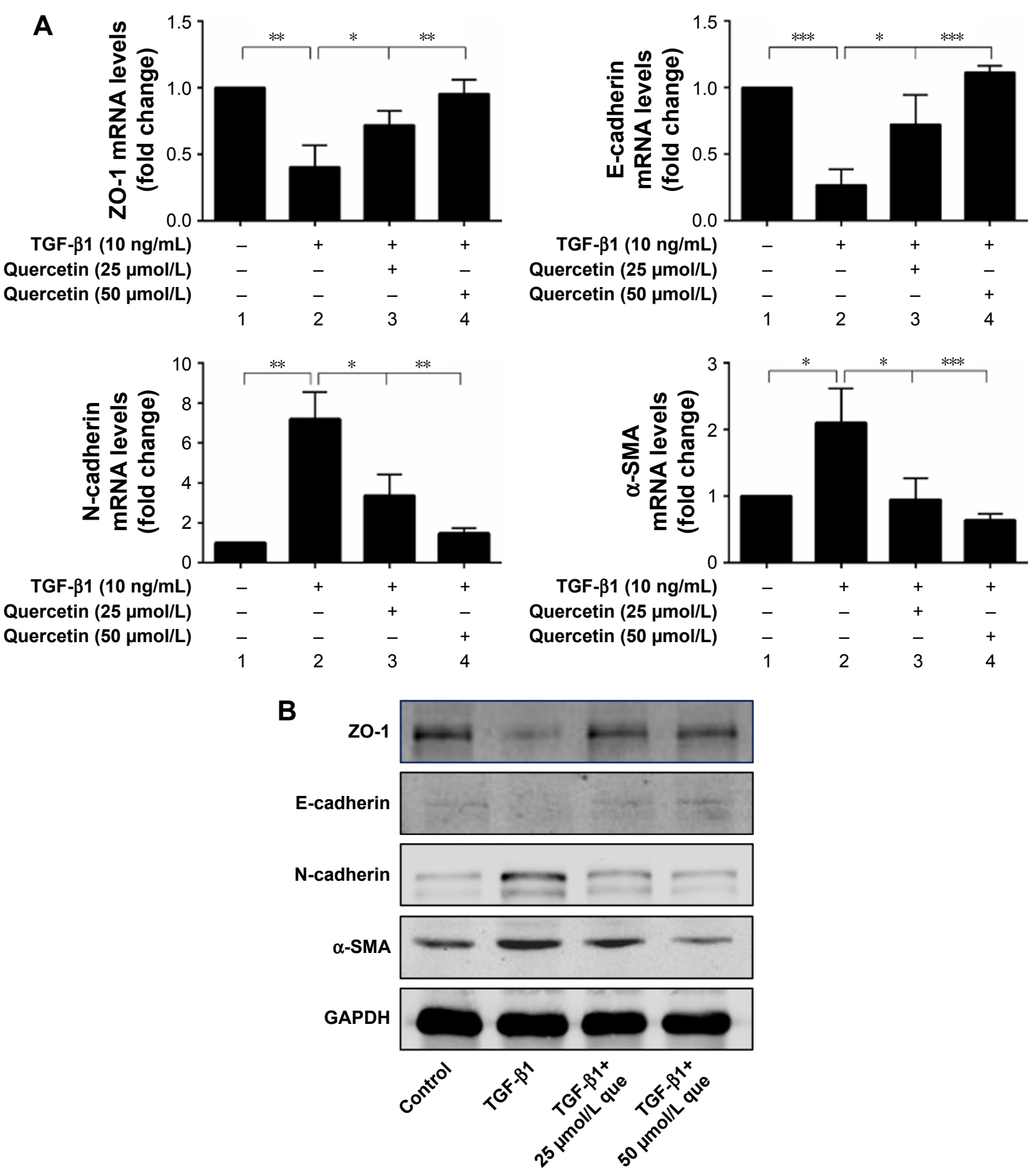

Figure 6 (Continued) 

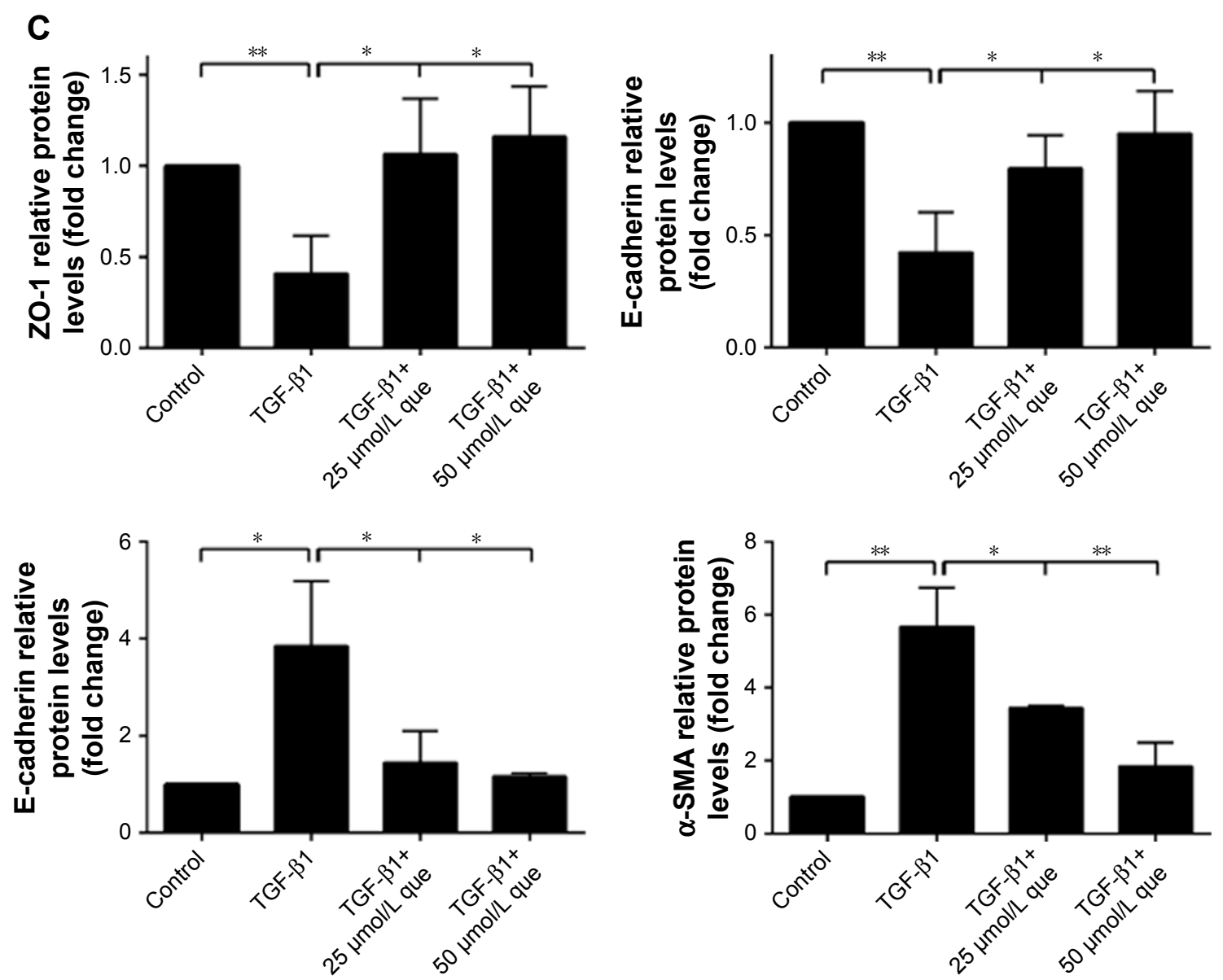

Figure 6 Quercetin suppressed TGF- $\beta$ I-induced EMT in RPE cells.

Notes: (A) The mRNA levels of EMT marker genes (ZO-I, E-cadherin, N-cadherin, and $\alpha$-SMA) were detected by real-time PCR. (B) The protein levels of EMT marker (ZO-I, E-cadherin, N-cadherin, and $\alpha$-SMA) were detected by Western blot in TGF- $\beta$ I and quercetin-treated RPE cells for 48 hours. (C) Relative protein expression (normalized to GAPDH) was quantified in Western blots via recording gray scale values. The data are presented as the mean $\pm \mathrm{SEM}$. $\mathrm{n}=3$. $* P<0.05$, $* * P<0.01, * * * P<0.001$.

Abbreviations: $\alpha$-SMA, $\alpha$-smooth muscle actin; EMT, epithelial-mesenchymal transition; que, quercetin; RPE, retinal pigment epithelial; ZO-I, zonula occludens-I.

inflammatory factors and cytokines such as Granulocyte colony-stimulating factor (Platelet-derived growth factor-bb G-CSF), Platelet-derived growth factor-bb (PDGF-bb), and $\mathrm{VEGF},{ }^{28}$ and macrophages release inflammatory cytokines, which trigger cell proliferation and migration. ${ }^{29}$ Fibroblasts might be involved in the contraction of epiretinal membranes, which would accelerate the progression of PVR. ${ }^{30}$ Various studies have illuminated that certain growth factors, cytokines, MMPs, and chemokines are present in the vitreous or subretinal fluid of PVR patients, ${ }^{31}$ and Hoerster et al indicated that several factors, such as TGF- $\beta 1$ and 2 , IL-6 and 8 , and $\mathrm{CC}$-chemokine ligand 2/monocyte chemoattractant protein, are involved in PVR development. ${ }^{32}$

There have been many efforts to prevent the occurrence or progression of PVR in the last few decades. ${ }^{2}$ Some therapeutic strategies, such as vitreous surgery or the use of pharmacologic agents, have been studied in PVR treatment. ${ }^{1}$ In 1984, corticosteroids were first studied in the rabbit vitreous in an experimental model of PVR. ${ }^{33}$ However, complications with secondary ocular hypertension after intravitreal injection of triamcinolone have been reported, ${ }^{34}$ and patients under PVR treatment had a poor response. ${ }^{35}$ Pharmacologic agents such as anti-inflammatory, anti-proliferative, or antioxidant agents have been investigated for PVR treatment. Anti-proliferative agents used in previous studies include curcumin, resveratrol, and epigallocatechin gallate. ${ }^{36-38}$ However, none of these compounds have been incorporated into clinical treatments. Thus, it is necessary to investigate additional pharmacologic agents in the treatment of PVR.

Quercetin exhibits beneficial properties such as antioxidative, anti-inflammatory, anti-angiogenic, and anticarcinogenic activities in various diseases. In 2011, Kviecinski et al reported that by acting as a free radical scavenger, quercetin effectively inhibited oxidative stress. ${ }^{39}$ Feng et al found that quercetin could 

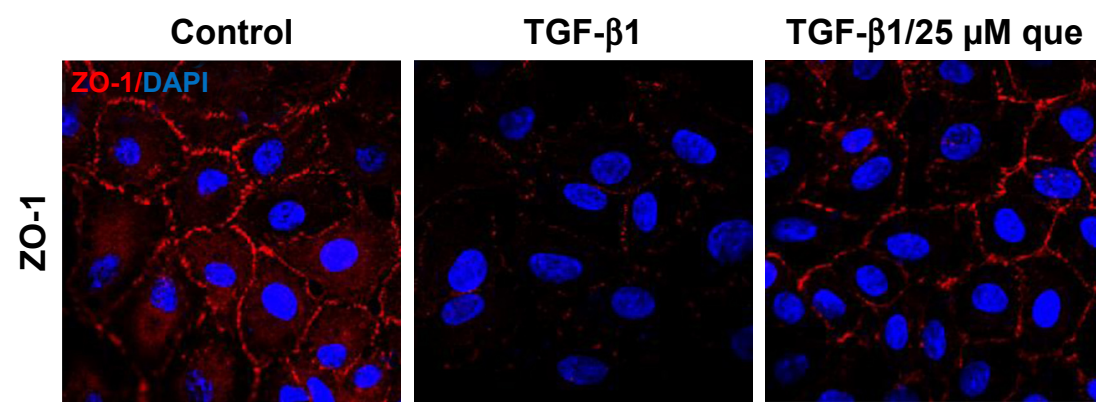

TGF- $\beta 1 / 25 \mu M$ que
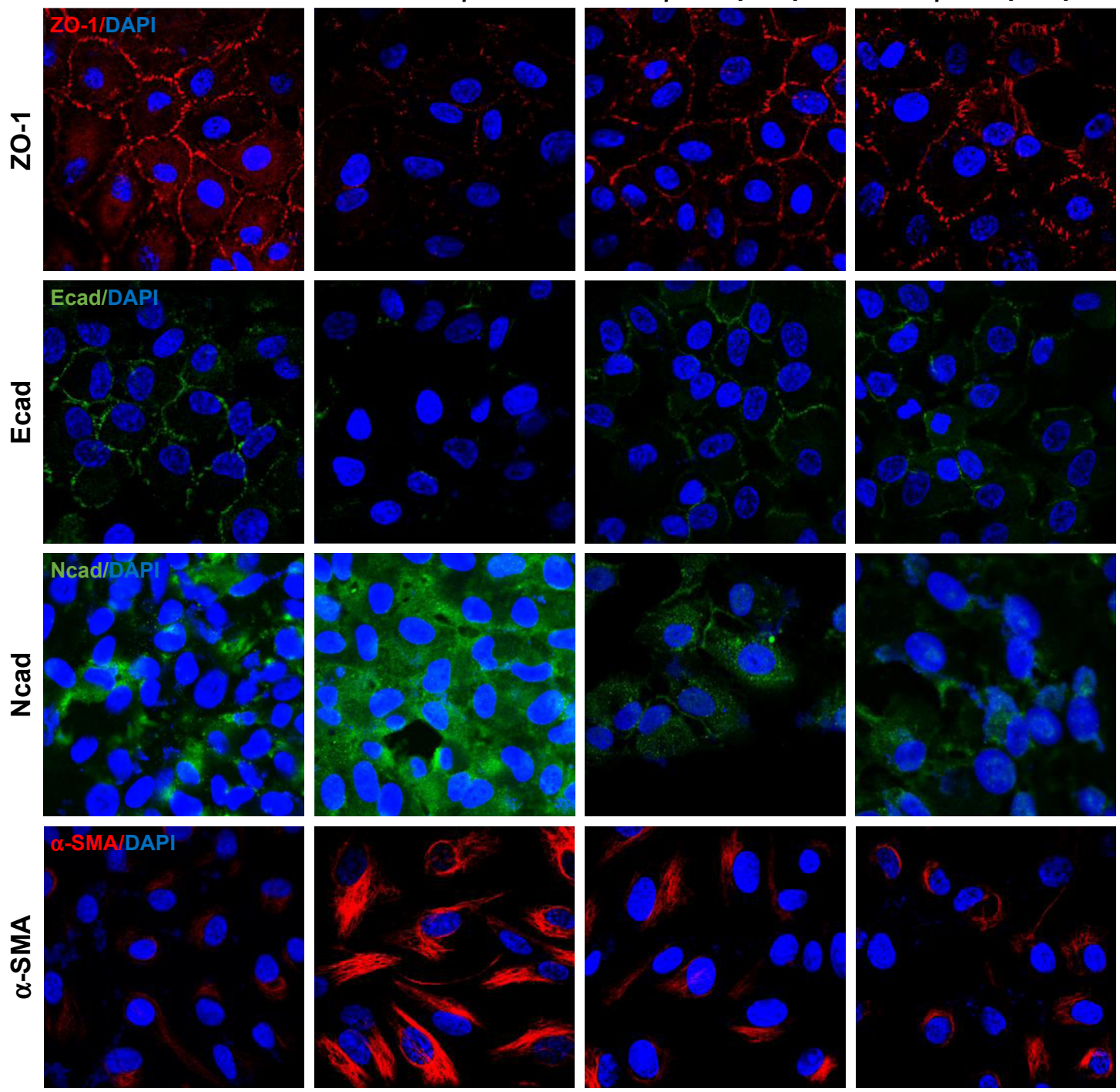

Figure 7 Immunofluorescence analysis of EMT-related proteins in ARPE-19 cells.

Notes: After RPE cells were treated with $10 \mathrm{ng} / \mathrm{mL}$ of TGF- $\beta$ I with or without quercetin (50 and I00 $\mu$ M) for 48 hours, ZO-I, E-cadherin, N-cadherin, and $\alpha$-SMA were detected using the primary antibody. DAPI was incubated to detect nuclei. The photos were recorded by confocal microscopy. Original magnification: $630 \times$, oil. Scale bar: $10 \mu \mathrm{m}$. Top to bottom: ZO-I.

Abbreviations: $\alpha$-SMA, $\alpha$-smooth muscle actin; Ecad, E-cadherin; EMT, epithelial-mesenchymal transition; Ncad, N-cadherin; que, quercetin; RPE, retinal pigment epithelial; TGF- $\beta$ I, transforming growth factor- $\beta$ I; ZO-I, zonula occludens-I.

restrain EMT by regulating E-cadherin expression, as enhancing E-cadherin expression restored cell-cell adhesion to prevent the progression of EMT. ${ }^{40}$ In ocular diseases, quercetin can protect the lens from oxidative damage and prevent cataract development due to its strong antioxidant and chelating properties. ${ }^{41}$

In our study, we investigated the effect of quercetin on ameliorating TGF- $\beta 1$-induced RPE cell proliferation, migration, and collagen secretion. First, RPE cells were exposed to various concentrations of TGF- $\beta 1$ for 24 and 48 hours to determine the most appropriate concentrations. As $10 \mathrm{ng} / \mathrm{mL}$ of TGF- $\beta 1$ could effectively accelerate proliferation, this was used in our experiments. Next, we treated these cells with quercetin to observe the effects on proliferation, and the results showed that quercetin could effectively inhibit TGF- $\beta 1$-induced cell proliferation at both 24 and 48 hours. TGF- $\beta 1$ caused the epithelial cells to transform their epithelial morphology to a mesenchymal morphology. RPE cell migration has a crucial role in the progression of PVR, and TGF- $\beta 1$ promoted cell migration, whereas quercetin suppressed migration in a concentration-dependent manner.

MMP-2 and MMP-9 were correlated with collagen and ECM protein production, which induced the development and progression of PVR. Wang et al reported that repression of MMP-2 and MMP-9 could markedly reverse EMT 
A

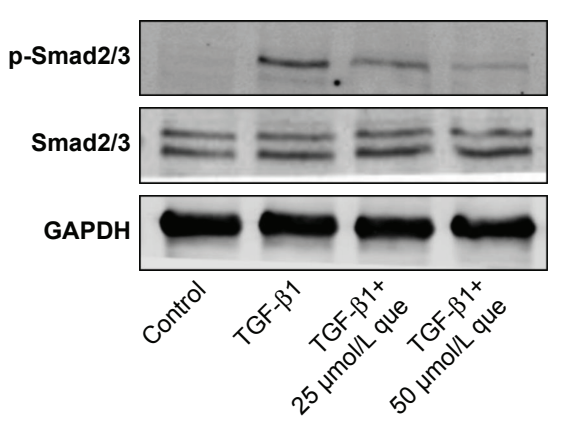

C

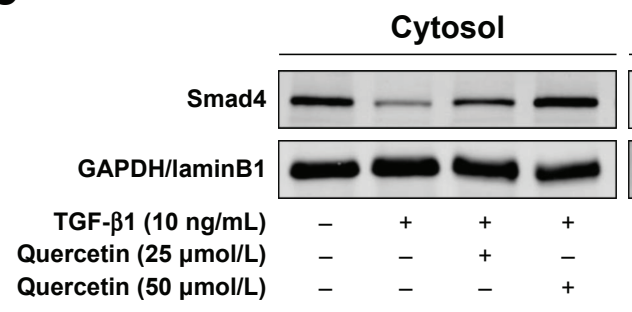

B

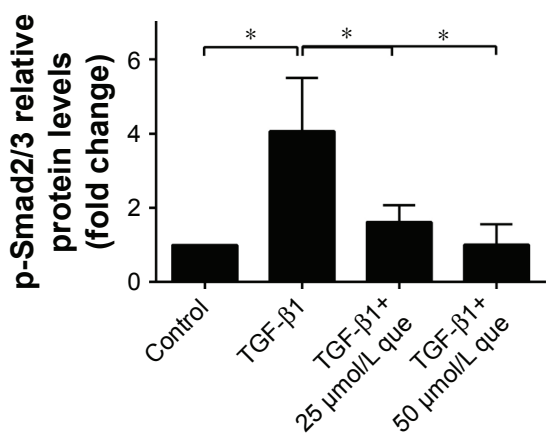

D

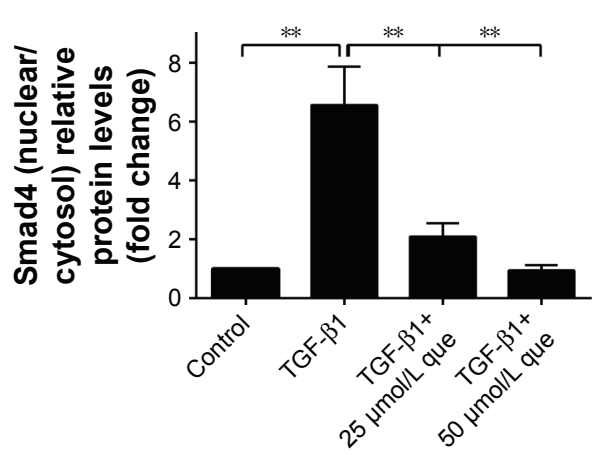

Figure 8 Quercetin attenuates TGF- $\beta$ I-induced Smad2/3 phosphorylation and nuclear translocation of Smad4 in RPE cells.

Notes: (A) The protein levels of p-smad2/3 were detected via Western blot in RPE cells treated with or without quercetin and TGF- $\beta$ I for 48 hours. (B) Quantitative data for p-Smad2/3 relative protein levels are calculated based on the expression of Smad2/3. (C) The protein levels of Smad4 in both cytoplasm and nucleus were detected via Western blot. (D) Quantitative data for Smad4 (nuclear vs cytosol ratio) relative protein levels are calculated. The results are presented as mean \pm SEM. $* P<0.05$, ** $P<0.01$.

Abbreviations: que, quercetin; RPE, retinal pigment epithelial; TGF- $\beta$ I, transforming growth factor- $\beta$ I.

in human non-small-cell lung cancer (NSCLC). ${ }^{42}$ Lin et al showed that inhibition of MMP-9 could reduce RPE cell migration so that ameliorated the PVR progression. ${ }^{10}$ In our studies, quercetin could markedly suppress the MMP-2 and MMP-9 expression. Thus, quercetin effectively decreased extracellular collagen production.

TGF- $\beta /$ Smad signaling pathway is involved in many diseases such as PVR,${ }^{43}$ multiorgan fibrosis, ${ }^{44-46}$ and cancers. ${ }^{47,48}$ TGF- $\beta$ induces the activation and phosphorylation of Smad2/3, forming trimers with Smad4. Then the complex is transported into the nucleus. Wu et al have shown that quercetin could inhibit Smad signaling pathway in the hepatic fibrosis animal model, and our results were consistent with it. ${ }^{49} \mathrm{Xin}$ et al reported that incubation with quercetin of 1,3 , and $10 \mu \mathrm{M}$ concentration for 48 hours could effectively inhibit Smad2/3 activation, which protected renal fibrosis of diabetic rats..$^{50} \mathrm{Lu}$ et al found that quercetin ameliorated kidney injury via the inactivation of TGF- $\beta 1 / \mathrm{Smad} 2 / 3$ signaling, which decreased the ECM production. ${ }^{51}$

In the present study, expression of the tight junction protein ZO-1 and E-cadherin was upregulated after incubation with quercetin, which contributed to maintaining epithelial cell properties. Loss of cell-cell adhesion plays a vital role in the progression of EMT, and E-cadherin is involved in EMT as a key mediator of cell-cell adhesion. The mesenchymal markers $\alpha$-SMA and N-cadherin were upregulated during EMT progression, and the ability of quercetin to modulate these markers would promote EMT. Our results show significant increases in phosphorylated Smad $2 / 3$ under TGF- $\beta 1$ stimulation, which was restrained by quercetin. These findings indicate that quercetin may prevent the development of EMT by regulating the $S m a d 2 / 3$ pathway.

There are some limitations to our study. First, we investigated the effect and mechanism of quercetin in cultured RPE cells. However, we did not establish an animal model of PVR, such as RPE cell-induced PVR in pigmented rabbits. Second, we elucidated the therapeutic effect of quercetin on TGF- $\beta 1$-induced EMT via the Smad-dependent signaling pathway, although other signaling pathways are involved in EMT. Thus, further studies should be applied to reveal the mechanism of quercetin in cell lines and PVR animal models to determine the underlying effects. 


\section{Conclusion}

We found that quercetin significantly suppressed TGF- $\beta 1$ induced proliferation and migration without influencing cell viability. Our findings suggest that quercetin is a potential therapeutic agent in PVR therapy. Further studies are needed to investigate the mechanisms in detail before the clinical application of quercetin.

\section{Acknowledgment}

This study was financially supported by the National Natural Science Foundation of China in 2014 (project number: 81470648) and the Fundamental Research Funds for the Central Universities.

\section{Disclosure}

The authors report no conflicts of interest in this work.

\section{References}

1. Sadaka A, Giuliari GP. Proliferative vitreoretinopathy: current and emerging treatments. Clin Ophthalmol. 2012;6:1325-1333.

2. Pastor JC, Rojas J, Pastor-Idoate S, Di Lauro S, Gonzalez-Buendia L, Delgado-Tirado S. Proliferative vitreoretinopathy: A new concept of disease pathogenesis and practical consequences. Prog Retin Eye Res. 2016;51:125-155

3. Shu DY, Lovicu FJ. Myofibroblast transdifferentiation: The dark force in ocular wound healing and fibrosis. Prog Retin Eye Res. 2017; 60:44-65.

4. Morescalchi F, Duse S, Gambicorti E, Romano MR, Costagliola C, Semeraro F. Proliferative vitreoretinopathy after eye injuries: an overexpression of growth factors and cytokines leading to a retinal keloid. Mediators Inflamm. 2013;2013:269787.

5. Cai W, Wei Q, Liu Q, et al. Effect of bradykinin on TGF- $\beta 1$-induced retinal pigment epithelial cell proliferation and extracellular matrix secretion. BMC Ophthalmol. 2016;16(1):199.

6. Wei Q, Liu Q, Ren C, et al. Effects of bradykinin on TGF- $\beta 1$-induced epithelial-mesenchymal transition in ARPE-19 cells. Mol Med Rep. 2018;17(4):5878-5886.

7. Ren YX, Ma JX, Zhao F, An JB, Geng YX, Liu LY. Effects of curcumin on epidermal growth factor in proliferative vitreoretinopathy. Cell Physiol Biochem. 2018;47(5):2136-2146.

8. Qiu S, Jiang Z, Huang Z, et al. Migration of retinal pigment epithelium cells is regulated by protein kinase $\mathrm{C} \alpha$ in vitro. Invest Ophthalmol Vis Sci. 2013;54(10):7082-7090.

9. González-Avila G, Méndez D, Lozano D, Ramos C, Delgado J, Iturria C. Role of retinal detachment subretinal fluid on extracellular matrix metabolism. Ophthalmologica. 2004;218(1):49-56.

10. Lin HY, Chen YS, Wang K, Chien HW, Hsieh YH, Yang SF. Fisetin inhibits epidermal growth factor-induced migration of ARPE-19 cells by suppression of AKT activation and Sp1-dependent MMP-9 expression. Mol Vis. 2017;23:900-910.

11. Srinivasan P, Vijayakumar S, Kothandaraman S, Palani M. Anti-diabetic activity of quercetin extracted from Phyllanthus emblica L. fruit: In silico and in vivo approaches. J Pharm Anal. 2018;8(2):109-118.

12. Cai HD, Su SL, Qian DW, et al. Renal protective effect and action mechanism of Huangkui capsule and its main five flavonoids. J Ethnopharmacol. 2017;206:152-159.

13. Wang J, Qian X, Gao Q, et al. Quercetin increases the antioxidant capacity of the ovary in menopausal rats and in ovarian granulosa cell culture in vitro. J Ovarian Res. 2018;11(1):51.
14. Meng LQ, Yang FY, Wang MS, et al. Quercetin protects against chronic prostatitis in rat model through NF- $\mathrm{KB}$ and MAPK signaling pathways. Prostate. 2018;78(11):790-800.

15. Şeker Karatoprak G, Aydin G, Altinsoy B, Altinkaynak C, Koşar M, Ocsoy I. The effect of pelargonium endlicherianum Fenzl. root extracts on formation of nanoparticles and their antimicrobial activities. Enzyme Microb Technol. 2017;97:21-26.

16. Balakrishnan S, Bhat FA, Raja Singh P, et al. Gold nanoparticleconjugated quercetin inhibits epithelial-mesenchymal transition, angiogenesis and invasiveness via EGFR/VEGFR-2-mediated pathway in breast cancer. Cell Prolif. 2016;49(6):678-697.

17. Song W, Zhao X, Xu J, Zhang H. Quercetin inhibits angiogenesismediated human retinoblastoma growth by targeting vascular endothelial growth factor receptor. Oncol Lett. 2017;14(3):3343-3348.

18. Yu D, Ye T, Xiang Y, et al. Quercetin inhibits epithelial-mesenchymal transition, decreases invasiveness and metastasis, and reverses IL-6 induced epithelial-mesenchymal transition, expression of MMP by inhibiting STAT3 signaling in pancreatic cancer cells. Onco Targets Ther. 2017;10:4719-4729.

19. Patel DH, Sharma N. Inhibitory effect of quercetin on epithelial to mesenchymal transition in SK-MEL-28 human melanoma cells defined by in vitro analysis on 3D collagen gels. Onco Targets Ther. 2016;9: 6445-6459.

20. Kook D, Wolf AH, Yu AL, et al. The protective effect of quercetin against oxidative stress in the human RPE in vitro. Invest Ophthalmol Vis Sci. 2008;49(4):1712-1720.

21. Du L, Hao M, Li C, et al. Quercetin inhibited epithelial mesenchymal transition in diabetic rats, high-glucose-cultured lens, and SRA01/04 cells through transforming growth factor- $\beta 2 /$ phosphoinositide 3-kinase/ Akt pathway. Mol Cell Endocrinol. 2017;452:44-56.

22. Oh HN, Kim CE, Lee JH, Yang JW. Effects of Quercetin in a Mouse Model of Experimental Dry Eye. Cornea. 2015;34(9):1130-1136.

23. Xu XR, Yu HT, Yang Y, Hang L, Yang XW, Ding SH. Quercetin phospholipid complex significantly protects against oxidative injury in ARPE-19 cells associated with activation of Nrf2 pathway. Eur J Pharmacol. 2016;770:1-8.

24. Stoddard AR, Koetje LR, Mitchell AK, Schotanus MP, Ubels JL. Bioavailability of antioxidants applied to stratified human corneal epithelial cells. J Ocul Pharmacol Ther. 2013;29(7):681-687.

25. Yu J, Liu F, Cui SJ, et al. Vitreous proteomic analysis of proliferative vitreoretinopathy. Proteomics. 2008;8(17):3667-3678.

26. Su CC, Chan CM, Chen HM, et al. Lutein inhibits the migration of retinal pigment epithelial cells via cytosolic and mitochondrial Akt pathways (lutein inhibits RPE cells migration). Int J Mol Sci. 2014; 15(8):13755-13767.

27. Khan MA, Brady CJ, Kaiser RS. Clinical management of proliferative vitreoretinopathy: an update. Retina. 2015;35(2):165-175.

28. Eastlake K, Banerjee PJ, Angbohang A, Charteris DG, Khaw PT, Limb GA. Müller glia as an important source of cytokines and inflammatory factors present in the gliotic retina during proliferative vitreoretinopathy. Glia. 2016;64(4):495-506.

29. Morescalchi F, Duse S, Gambicorti E, Romano MR, Costagliola C, Semeraro F. Proliferative vitreoretinopathy after eye injuries: an overexpression of growth factors and cytokines leading to a retinal keloid. Mediators Inflamm. 2013;2013:269787.

30. Garweg JG, Tappeiner C, Halberstadt M. Pathophysiology of proliferative vitreoretinopathy in retinal detachment. Surv Ophthalmol. 2013; 58(4):321-329.

31. Ciprian D. The pathogeny of proliferative vitreoretinopathy. Rom $J$ Ophthalmol. 2015;59(2):88-92.

32. Hoerster R, Fauser S, Cursiefen C, Kirchhof B, Heindl LM. The influence of systemic renin-angiotensin-inhibition on ocular cytokines related to proliferative vitreoretinopathy. Graefes Arch Clin Exp Ophthalmol. 2017;255(9):1721-1725.

33. Sunalp M, Wiedemann P, Sorgente N, Ryan SJ. Effects of cytotoxic drugs on proliferative vitreoretinopathy in the rabbit cell injection model. Curr Eye Res. 1984;3(4):619-623. 
34. Jonas JB, Kreissig I, Degenring RF. Treatment of oedematous, proliferative and neovascular diseases by intravitreal triamcinolone acetonide. Klin Monbl Augenheilkd. 2003;220(6):384-390. German.

35. Moysidis SN, Thanos A, Vavvas DG. Mechanisms of inflammation in proliferative vitreoretinopathy: from bench to bedside. Mediators Inflamm. 2012;2012:815937.

36. Ishikawa K, He S, Terasaki H, et al. Resveratrol inhibits epithelialmesenchymal transition of retinal pigment epithelium and development of proliferative vitreoretinopathy. Sci Rep. 2015;5:16386.

37. Alex AF, Spitznas M, Tittel AP, Kurts C, Eter N. Inhibitory effect of epigallocatechin gallate (EGCG), resveratrol, and curcumin on proliferation of human retinal pigment epithelial cells in vitro. Curr Eye Res. 2010;35(11):1021-1033.

38. Zhou X, Kuang X, Long C, et al. Curcumin Inhibits Proliferation and Epithelial-Mesenchymal Transition of Retinal Pigment Epithelial Cells Via Multiple Pathways. Curr Mol Med. 2017;17(4):312-319.

39. Kviecinski MR, Felipe KB, Correia JF, et al. Brazilian Bidens pilosa Linné yields fraction containing quercetin-derived flavonoid with free radical scavenger activity and hepatoprotective effects. Libyan J Med. 2011;6:5651.

40. Feng J, Song D, Jiang S, et al. Quercetin restrains TGF- $\beta 1$-induced epithelial-mesenchymal transition by inhibiting Twist 1 and regulating E-cadherin expression. Biochem Biophys Res Commun. 2018;498(1): 132-138

41. Ferlemi AV, Makri OE, Mermigki PG, Lamari FN, Georgakopoulos CD. Quercetin glycosides and chlorogenic acid in highbush blueberry leaf decoction prevent cataractogenesis in vivo and in vitro: Investigation of the effect on calpains, antioxidant and metal chelating properties. Exp Eye Res. 2016;145:258-268.

42. Wang Z, Lu Y, Sheng B, Ding Y, Cheng X. Catalpol inhibits TGF$\beta 1$-induced epithelial-mesenchymal transition in human non-small-cell lung cancer cells through the inactivation of Smad $2 / 3$ and NF- $\kappa \mathrm{B}$ signaling pathways. J Cell Biochem. Epub 2018 Nov 7.
43. Chen CL, Chen YH, Tai MC, Liang CM, Lu DW, Chen JT. Resveratrol inhibits transforming growth factor- $\beta 2$-induced epithelialto-mesenchymal transition in human retinal pigment epithelial cells by suppressing the Smad pathway. Drug Des Devel Ther. 2017;11: $163-173$.

44. Ji X, Wang H, Wu Z, et al. Specific Inhibitor of Smad3 (SIS3) Attenuates Fibrosis, Apoptosis, and Inflammation in Unilateral Ureteral Obstruction Kidneys by Inhibition of Transforming Growth Factor $\beta$ (TGF- $\beta$ )/ Smad3 Signaling. Med Sci Monit. 2018;24:1633-1641.

45. Zhang ZH, Li MH, Liu D, et al. Rhubarb Protect Against Tubulointerstitial Fibrosis by Inhibiting TGF- $\beta /$ Smad Pathway and Improving Abnormal Metabolome in Chronic Kidney Disease. Front Pharmacol. 2018;9:1029.

46. Ma L, Zeng Y, Wei J, et al. Knockdown of LOXL1 inhibits TGF$\beta 1$-induced proliferation and fibrogenesis of hepatic stellate cells by inhibition of Smad2/3 phosphorylation. Biomed Pharmacother. 2018; 107:1728-1735.

47. Zeng Y, Zhu J, Shen D, et al. Repression of Smad4 by miR-205 moderates TGF- $\beta$-induced epithelial-mesenchymal transition in A549 cell lines. Int J Oncol. 2016;49(2):700-708.

48. Tao S, Liu M, Shen D, Zhang W, Wang T, Bai Y. TGF- $\beta$ /Smads Signaling Affects Radiation Response and Prolongs Survival by Regulating DNA Repair Genes in Malignant Glioma. DNA Cell Biol. Epub 2018 Sep 19.

49. Wu L, Zhang Q, Mo W, et al. Quercetin prevents hepatic fibrosis by inhibiting hepatic stellate cell activation and reducing autophagy via the TGF- $\beta 1 /$ Smads and PI3K/Akt pathways. Sci Rep. 2017;7(1):9289.

50. Xin X, Li XH, Wu JZ, et al. Pentamethylquercetin ameliorates fibrosis in diabetic Goto-Kakizaki rat kidneys and mesangial cells with suppression of TGF- $\beta /$ Smads signaling. Eur J Pharmacol. 2013;713(1-3): $6-15$.

51. Lu H, Wu L, Liu L, et al. Quercetin ameliorates kidney injury and fibrosis by modulating M1/M2 macrophage polarization. Biochem Pharmacol. 2018;154:203-212.

\section{Publish your work in this journal}

Drug Design, Development and Therapy is an international, peerreviewed open-access journal that spans the spectrum of drug design and development through to clinical applications. Clinical outcomes, patient safety, and programs for the development and effective, safe, and sustained use of medicines are the features of the journal, which

\section{Dovepress}

has also been accepted for indexing on PubMed Central. The manuscript management system is completely online and includes a very quick and fair peer-review system, which is all easy to use. Visit http://www.dovepress.com/testimonials.php to read real quotes from published authors.

Submit your manuscript here: http://www.dovepress.com/drug-design-development-and-therapy-journal 